\title{
Antibacterial activity of the alkaloid extract and isolated compounds from Croton bonplandianum Baill. (Euphorbiaceae)
}

BURGOS, A.'; BARUA, J.'; FLORES-GIUBI, M.E.'; BAZAN, D.1; FERRO, E.'; ALVARENGA, N.L.."* ${ }_{1}$ Departamento de Fitoquímica, Dirección de Investigación, Facultad de Ciencias Químicas, Universidad Nacional de Asunción, Campus Universitario de San Lorenzo Km 9,5, PO BOX 1055, San Lorenzo, Paraguay. *Autor para correspondência: nelson@qui.una.py

\begin{abstract}
The antibacterial activity of the alkaloid extract from the leaves of Croton bonplandianum Baill. and its main compounds, sparsiflorine and crotsparine, was tested against Staphylococcus aureus, Escherichia coli, Klebsiella pneumoniae and Pseudomonas aeruginosa by the resazurin microtitre-plate method. Pure compounds were identified by spectroscopic techniques, mainly $1 \mathrm{D}$ and $2 \mathrm{D}$ NMR. The alkaloid extract showed activity particularly against the $S$. aureus and $P$. aeruginosa. Regarding the pure compounds, the crotsparine was inactive against the microorganisms assayed, whereas the sparsiflorine indicated a moderate activity similar to the alkaloid extract. The Pseudomonas aeruginosa was the most sensitive of the tested microorganisms with MIC of $0.141 \mathrm{mg} / \mathrm{mL}$. The results suggest that the activity of the extract may be credited mainly to the presence of the sparsiflorine. Although the activity of the sparsiflorine does not get close to the antimicrobial drugs in clinical use, it still could be a lead compound for the development of new antibacterial substances.
\end{abstract}

Keywords: alkaloids, sparsiflorine, crotsparine, antibacterial activity, Croton bonplandianum, Euphorbiaceae.

RESUMO: Atividade anti-bacteriana do extrato alcaloide e de compostos isolados de Croton bonplandianum Baill. (Euphorbiaceae). A atividade antibacteriana do extrato alcaloidal das folhas de Croton bonplandianum Baill., além dos principais compostos isolados, esparsiflorina e crotsparina, foi testada contra Staphylococcus aureus, Escherichia coli, Klebsiella pneumoniae e Pseudomonas aeruginosa. Foi utilizado o método de microdiluição em placa empregando resazurina como indicador da viabilidade celular. Os compostos isolados foram identificados por técnicas espectroscópicas, principalmente RMN 1D e 2D. O extrato alcaloidal foi ativo principalmente contra $S$. aureus e $P$. aeruginosa. Crotsparina mostrou-se inativa contra todos os micro-organismos testados, enquanto esparsiflorina apresentou atividade moderada, a qual foi similar à do extrato bruto. Pseudomonas aeruginosa foi a mais sensível das bactérias testadas, com CIM de $0,141 \mathrm{mg} / \mathrm{mL}$. Os resultados sugerem que a atividade do extrato pode ser devida em grande medida pela presença de esparsiflorina. Apesar de a CIM da esparsiflorina não ter se aproximado daquela apresentada pelos agentes antimicrobianos em uso clínico, tal composto ainda pode compor um protótipo interessante para o desenvolvimento de novas substâncias antibacterianas.

Palavras-chaves: alcaloides, esparsiflorina, crotsparina, atividade antibacteriana, Croton bonplandianum, Euphorbiaceae.

\section{INTRODUCTION}

In recent years, the continuous emergence of resistant or multi-resistant strains of microorganisms towards the drugs used clinically raises the need for the search of new antimicrobial substances that could be used for the treatment of the infections produced by those strains (Suleiman et al., 2010).

Within this context, plants are an important source of molecules, which can become lead substances for the development of new antimicrobial drugs. In fact, it is estimated that natural products are involved in the development of the $44 \%$ of all new drug molecules, mainly as a basis for obtaining 
semisynthetic derivatives (Hostettmann et al., 2001; Lahlou, 2013).

Croton bonplandianum Baill (Syn. Croton sparsiflorus Morong) is a weed native of South America but naturalized in the Indian subcontinent. Since the early 60's, the plant was intensively studied and many alkaloids were isolated. Crotsparine (1), sparsiflorine (2) and other compounds were described in the literature (Chatterjee et al, 1965; Bhakuni \& Dhar, 1968). According to Bhakuni et al. (1970), the relative concentration of the alkaloids isolated from the plant varies seasonally. In this work, we found that $C$. bonplandianum that grows in Paraguay produces crotsparine and sparsiflorine as its main alkaloids.

Crotsparine (1) is a proaporphine alkaloid and sparsiflorine (2) is an aporphine (Figure 1). Crotsparine rearranges into sparsiflorine in acidic media and, according to the most accepted biosynthetic pathway, sparsiflorine is produced from crotsparine via a dienone-phenol rearrangement (Bhakuni et al., 1974).

Despite the fact that these compounds are known from almost sixty years, few works related to the biological activity of the pure substances isolated from the plant are reported in the literature. Most of the articles deal with the antimicrobial activity of crude extracts, obtained with different solvents.

In this context, Singh et al. (2010) and Jeeshna et al. (2011) evaluated the antimicrobial activity of extracts obtained from leaves and fruits of $C$. bonplandianum against fungi and bacteria by the disc diffusion method. In both cases, the results obtained showed that the methanolic extract was the most active, but the activities of single compounds were not reported.

Udaya et al. (2011) reported maximum activity against Bacillus subtilis and Staphylococcus aureus for the methanolic extract. Previously, an ethanolic extract of the whole plant was also assayed and Pseudomonas aeruginosa was the most sensitive of the tested bacteria (Parmesha et al., 2008).

The aqueous extracts of different parts of the plant showed allelopathic effect on some crop and weed plants (Sisodia \& Siddiqui, 2010) and the methanolic extract of the twigs inhibited gall-tumors induced by Agrobacterium tumefaciens (Islam et al., 2011).

Regarding pure compounds, crotsparine is the most studied. It showed activity against the chloroquine-resistant $\mathrm{K} 1$ and $\mathrm{FcB} 1$ strains of Plasmodium falciparum (Akendengue et al., 2002). Concerning the antibacterial activity, Legoabe (2004) assayed crotsparine against Bacillus subtillis, Pseudomonas aeruginosa, Escherichia coli, Staphylococcus aureus and Candida albicans and the MIC values were over $1 \mathrm{mg} / \mathrm{mL}$ for all the microorganisms tested. However, at higher concentrations the compound showed some activity against $E$. coli (MIC $1.87 \mathrm{mg} / \mathrm{mL})$.

With these antecedents, we decide to test the antibacterial activity of the alkaloid extract obtained from the leaves of $C$. bonplandianum that grows in Paraguay and also of the pure compounds isolated from it.

\section{MATERIAL AND METHOD \\ Plant material}

Specimens of C. bonplandianum (whole plant) were collected in Guarambaré, Central Department, Paraguay, on October 2013. Samples were authenticated by Prof. Rosa Deguen and a voucher specimen is deposited in the Herbarium FCQ of the Facultad de Ciencias Químicas, Universidad Nacional de Asunción, Paraguay (R. Degen 3757).

\section{Chemical reagents and supplies}

All the chemicals were analytical grade, and were purchased from Merck $K G a A$, Darmstadt, Germany, and from Biopack and Research AG, Buenos Aires, Argentine. Resazurin was from Sigma-Aldrich, St. Louis, MO, USA. The culture media were from HiMedia Laboratories PVT. Ltd, India. Gentamicin was obtained from a local pharmaceutical company. The 96 well plates (sterile, with lid) were purchased from Brand $\mathrm{GMBH}+\mathrm{CO}$ KG, Wertheim, Germany. Silica gel TLC plates $(0.25 \mathrm{~mm}$ thickness, with fluorescent indicator $254 \mathrm{~nm}$ ) were from Sigma-Aldrich Co, MO, USA. Silica gel for column chromatography (0.063-0.2 $\mathrm{mm}$ particle diameter) was also of Merck. Oleum, used as universal visualizing reagent for TLC, was composed by a mixture of $\mathrm{CH}_{3} \mathrm{COOH}: \mathrm{H}_{2} \mathrm{O}: \mathrm{H}_{2} \mathrm{SO}_{4}$ in proportion 80: 16: 4.

\section{Instruments}

The NMR experiments were performed with a Varian Inova 400 or with an Agilent 500 NMR spectrometers (Agilent Technologies, Santa Clara, CA, USA) at 400 or $500 \mathrm{MHz}$ for ${ }^{1} \mathrm{H}$ NMR and at 100 or $125 \mathrm{MHz}$ for ${ }^{13} \mathrm{C}$ NMR. The MS spectrum was taken with a Waters Xevo-TQD triple quadrupole mass spectrometer (Waters Corporation, Milford, MA, USA). The IR spectrum was recorded with a Shimadzu IR Prestige-21 apparatus and the UV spectrum was taken with a Shimadzu UV-1800 spectrophotometer (Shimadzu Corporation, Tokyo, Japan). The bacterial suspension density was adjusted with a Hach 2100 AN tubidimeter (Hach Company, Loveland, CO, USA). 


\section{Extract preparation}

The plant material (200 g approximately) was dried in a forced-air circulation oven, at $40^{\circ} \mathrm{C}$. The leaves were separated and grinded in a cutter mill to fine powder. This material $(77.8 \mathrm{~g})$ was macerated with $5 \% \mathrm{HCl}$ for 24 hours. Then, it was filtered through quantitative paper and the process was repeated twice. The filtrates were collected, mixed and extracted three times with chloroform in a separatory funnel and the organic layers were separated. The aqueous portion was render alkaline with $20 \% \mathrm{NaOH}$ to $\mathrm{pH} 11$ and extracted again with chloroform three times. The organic layers were mixed and the solvent removed in a rotary evaporator $\left(40^{\circ} \mathrm{C}\right)$ in order to obtain the crude alkaloid extract.

\section{Isolation of pure compounds}

The alkaloid extract was analyzed initially by TLC with silica gel 60 as stationary phase, and different chloroform - methanol mixtures as eluent, and visualized by UV light (254 and $366 \mathrm{~nm}$ ) and by spraying with Dragendorff reagent. In order to reveal non-alkaloid compounds, Oleum (a universal developing reagent) was used. No additional spots were observed.

In order to separate the main constituents visualized by TLC, the extract was submitted to repeated column chromatography at medium and atmospheric pressure with silica gel as stationary phase and different mixtures of chloroform and methanol as mobile phase. Two pure alkaloids were obtained and identified as crotsparine and sparsiflorine by 1D and 2D NMR spectroscopy and by comparison of the data obtained with those found in the literature (Chatterjee et al, 1965; Bhakuni \& Dhar, 1968; Akendengue et al., 2002).

Crotsparine (1): White amorphous powder; UV (MeOH): $\lambda_{\max }=288,235,210 \mathrm{~nm}$; IR $\left(\mathrm{CH}_{2} \mathrm{Cl}_{2}\right)$ : $\mathrm{V}_{\max }=3532,3054,2987,1664,1607,1492,1379$, 1255, $859 \mathrm{~cm}^{-1}$; ESIMS (MeOH): $\mathrm{m} / \mathrm{z}=284\left(\mathrm{MH}^{+}\right)$; ${ }^{1} \mathrm{H} \mathrm{NMR}\left(400 \mathrm{MHz}, \mathrm{CD}_{3} \mathrm{OD}\right)$ and ${ }^{13} \mathrm{C}$ NMR $(100 \mathrm{MHz}$, $\mathrm{CD}_{3} \mathrm{OD}$ ) see Table 1.

Sparsiflorine (2): White amorphous powder; UV (EtOH): $\lambda_{\max }=308,276,267,217 \mathrm{~nm}$; IR $\left(\mathrm{CH}_{2} \mathrm{Cl}_{2}\right): \mathrm{v}_{\max }=3685,3588,3431,3059,2935,1607$, 1462, 1379, 1276, 1126, $839 \mathrm{~cm}^{-1}$; ESIMS (MeOH): $\mathrm{m} / \mathrm{z}=284\left(\mathrm{MH}^{+}\right) ;{ }^{1} \mathrm{H} \mathrm{NMR}\left(500 \mathrm{MHz}, \mathrm{CDCl}_{3}\right)$ and ${ }^{13} \mathrm{C}$ NMR $\left(125 \mathrm{MHz}, \mathrm{CDCl}_{3}\right)$ see Table 1.

\section{Antibacterial activity}

The antibacterial activity was assayed by the method proposed by Sarker et al. (2007) with slight modifications.

\section{Microorganisms}

Strains of Escherichia coli (American Type Culture Collection, ATCC 35218), Klebsiella pneumoniae (Colección Española de Cultivos Tipo, CECT 367), Staphylococcus aureus (ATCC 25923) and Pseudomonas aeruginosa (CECT 108) were

TABLE 1. ${ }^{1 \mathrm{H}}$ and ${ }^{13} \mathrm{C}$ NMR chemical shifts (d) of crotsparine (1) and sparsiflorine (2)

\begin{tabular}{|c|c|c|c|}
\hline 1 & & 2 & \\
\hline${ }^{1} \mathrm{H}$ & ${ }^{13} \mathrm{C}$ & ${ }^{1} \mathrm{H}$ & ${ }^{13} \mathrm{C}$ \\
\hline $7.15(1 \mathrm{H}, \mathrm{dd}, J=9.9,2.8 \mathrm{~Hz}, \mathrm{H}-8)$ & $187.56(\mathrm{C}-10)$ & $7.93(1 \mathrm{H}, \mathrm{d}, J=2.6 \mathrm{~Hz}, \mathrm{H}-11)$ & $154.57(C-10)$ \\
\hline $6.99(1 \mathrm{H}, \mathrm{dd}, J=9.9,2,8 \mathrm{~Hz}, \mathrm{H}-12)$ & $155.79(\mathrm{C}-12)$ & $7.10(1 \mathrm{H}, \mathrm{d}, J=8.1 \mathrm{~Hz}, \mathrm{H}-8)$ & $145.73(\mathrm{C}-2)$ \\
\hline $6.67(1 \mathrm{H}, \mathrm{s}, \mathrm{H}-3)$ & $151.80(\mathrm{C}-8)$ & $6.70(1 \mathrm{H}, \mathrm{dd}, J=8.1,2.6 \mathrm{~Hz}, \mathrm{H}-9)$ & $141.28(\mathrm{C}-1)$ \\
\hline $6.31(1 \mathrm{H}, \mathrm{dd}, J=9.9,1.9 \mathrm{~Hz}, \mathrm{H}-9)$ & 148.59 (C-2) & $6.59(1 \mathrm{H}, \mathrm{s}, \mathrm{H}-3)$ & $133.10(\mathrm{C}-11 \mathrm{a})$ \\
\hline $6.23(1 \mathrm{H}, \mathrm{dd}, J=9.9,1.9 \mathrm{~Hz}, \mathrm{H}-11)$ & $141.87(\mathrm{C}-1)$ & $3.92\left(3 \mathrm{H}, \mathrm{s}, \mathrm{OCH}_{3}\right)$ & $128.85(\mathrm{C} 1 \mathrm{~b})$ \\
\hline $4.32-4.22(1 \mathrm{H}, \mathrm{m}, \mathrm{H}-6 \mathrm{a})$ & $135.04(\mathrm{C}-7 \mathrm{c})$ & $3.84(1 \mathrm{H}, \mathrm{dd}, J=13.6,4.7 \mathrm{~Hz}, \mathrm{H}-6 \mathrm{a})$ & $128.45(\mathrm{C}-8)$ \\
\hline $3.79\left(3 \mathrm{H}, \mathrm{s}, \mathrm{OCH}_{3}\right)$ & $127.62(\mathrm{C}-9)$ & $3.37(1 \mathrm{H}, \mathrm{m}, \mathrm{H}-5)$ & $127.45(\mathrm{C}-7 \mathrm{a})$ \\
\hline $3.42-3.27(1 \mathrm{H}, \mathrm{m}, \mathrm{H}-5)$ & $126.45(\mathrm{C}-11)$ & $3.00\left(2 \mathrm{H}, \mathrm{m}, \mathrm{H}-4, \mathrm{H}-5^{\circ}\right)$ & $123.84(\mathrm{C}-3 \mathrm{a})$ \\
\hline $3.09\left(1 \mathrm{H}, \mathrm{ddd}, J=12.8,11.0,6.0 \mathrm{~Hz}, \mathrm{H}-5{ }^{5}\right)$ & 124.09 (C-7b) & $2.80(1 \mathrm{H}, \mathrm{dd}, J=13.7,4.6 \mathrm{~Hz}, \mathrm{H}-7)$ & $118.81(\mathrm{C}-1 \mathrm{a})$ \\
\hline $2.85-2.64(2 \mathrm{H}, \mathrm{m}, \mathrm{H}-4)$ & $122.83(\mathrm{C}-3 \mathrm{a})$ & $2.65\left(2 \mathrm{H}, \mathrm{m}, \mathrm{H}-4^{*}, \mathrm{H}-7^{*}\right)$ & $115.35(\mathrm{C}-11)$ \\
\hline $2.33(1 \mathrm{H}, \mathrm{dd}, J=11.9,6.4 \mathrm{~Hz}, \mathrm{H}-7)$ & $110.68(C-3)$ & & $113.85(\mathrm{C}-9)$ \\
\hline \multirow[t]{6}{*}{$2.21\left(1 \mathrm{H}, \mathrm{dd}, J=11.9,10.6 \mathrm{~Hz}, \mathrm{H}-7^{*}\right)$} & 57.40 (C-6a) & & $109.91(\mathrm{C}-3)$ \\
\hline & $55.75\left(\mathrm{OCH}_{3}\right)$ & & $56.09\left(\mathrm{OCH}_{3}\right)$ \\
\hline & $51.32(C-7 a)$ & & $53.72(\mathrm{C}-6 \mathrm{a})$ \\
\hline & $47.22(\mathrm{C}-7)$ & & $43.06(C-5)$ \\
\hline & $44.61(\mathrm{C}-5)$ & & $36.35(\mathrm{C}-7)$ \\
\hline & $25.30(C-4)$ & & $28.81(C-4)$ \\
\hline
\end{tabular}

\footnotetext{
* Indicates the second proton of a methylene group
} 
used. The microorganisms were maintained at $-20^{\circ} \mathrm{C}$ in nutrient broth with $15 \%$ glycerol. To prepare the working inoculum, a small portion was taken aseptically and transferred to a screw cap tube with $15 \mathrm{~mL}$ of Mueller-Hinton broth and incubated for 24 $\mathrm{h}$ at $36 \pm 1{ }^{\circ} \mathrm{C}$. The bacterial suspension was diluted with sterile saline solution to a turbidity equivalent to a $0.5 \mathrm{McF}$ arland standard using a turbidimeter. This resulted in a suspension containing approximately 1 $\times 10^{8} \mathrm{CFU} / \mathrm{mL}$. The standardized suspensions were diluted 1:20 with sterile saline solution to yield $5 \mathrm{x}$ $10^{\circ} \mathrm{CFU} / \mathrm{mL}$.

\section{MIC determination}

Microtitration 96 well plates were prepared under aseptic conditions using a biological safety cabinet (Forma Scientific, Inc., Marietta, OH, USA). The extract and the pure compounds were weighed in sterile vials and dissolved with DMSO. Mueller-Hinton broth was added in order to obtain a concentration of $10 \mathrm{mg} / \mathrm{mL}$ for the extract and 1 $\mathrm{mg} / \mathrm{mL}$ for pure compounds. The concentration of DMSO in the final solution was $10 \%$. A volume of $100 \mu \mathrm{L}$ of the tested material was transferred to the first vertical row of the plates. To all the other wells $50 \mu \mathrm{L}$ of Mueller-Hinton broth was added. With the aid of a multichannel pipette, $50 \mu \mathrm{L}$ were taken from the first row and serial dilutions were performed, in order that all wells had $50 \mu \mathrm{L}$ of the substance assayed in serially descending concentrations. The last $50 \mu \mathrm{L}$ aliquots were discarded. To all of the wells in the plate, $40 \mu \mathrm{L}$ of broth were added plus $10 \mu \mathrm{L}$ of the bacterial suspension. Two horizontal rows were reserved for growth control and sterility control. To the first row was added broth + DMSO + microorganism and for the second only broth + DMSO. The DMSO concentration was $10 \%$ in these two rows. The last horizontal row was reserved for the control substance (gentamicin) also in serial dilutions. The final volume in all rows was $100 \mu \mathrm{L}$.

The plates were incubated at $36 \pm 1^{\circ} \mathrm{C}$ for 24 h. After that, $10 \mu \mathrm{L}$ of resazurin solution $(6.75 \mathrm{mg} / \mathrm{mL})$ was added and the plates were incubated again for $2 \mathrm{~h}$. The plates were then checked visually. A color change from deep blue to pink was interpreted as positive bacterial growth. The MIC was recorded as the lowest concentration where no color change occurred. The experiments were performed in quadruplicates for all the microorganisms assayed.

\section{Statistical analysis}

Data were analyzed by a paired Student " $\mathrm{t}$ " test using the SPSS software, version 22.0 (IBM, New York, USA) with a confidence interval of $95 \%$. Observed differences between treatments were considered statistically significant when p-value < 0.05 .

\section{RESULTS AND DISCUSSION}

The extraction process let to get $0.871 \mathrm{~g}$ of crude alkaloid extract ( $1.12 \%$ yield).

TLC analysis revealed two main alkaloids, in approximate ratio 2: 1 and other very minor compounds. The extract was submitted to column chromatography in order to isolate the major alkaloids. Only a small amount of the two compounds were obtained from the alkaloid extract, due to it instability.

Compound 1 (which was present in lesser amount between the two main alkaloids according to the TLC) was isolated as an amorphous white solid (10.0 mg; $1.15 \%$ of the alkaloid extract) which rapidly turns dark red in solution when exposed to light and air. The compound was identified as crotsparine by comparison of the obtained data with those present in the literature, (Bhakuni \& Dhar, 1968; Akendengue et al., 2002).

Compound 2 (the major alkaloid based on TLC results) was obtained as an amorphous white solid $(8.0 \mathrm{mg} ; 0.92 \%$ of the extract), that also decomposed by light and air exposition, as in the previous case (Chatterjee et al., 1965). It ${ }^{1} \mathrm{H}$ NMR spectrum showed signals characteristic of a 1,2,10-oxygenated aporphine in the aromatic region (two doublets, a double doublet and a singlet). Analysis of the proton and ${ }^{13} \mathrm{C}$ NMR spectra suggested the possibility of the isolated compound to be sparsiflorine. Nevertheless, comparing the data obtained with those of the literature was inconclusive, considering that the ${ }^{1} \mathrm{H}$ NMR spectrum described in the original paper was taken in $\mathrm{CF}_{3} \mathrm{COOH}$ and data about the ${ }^{13} \mathrm{C}$ NMR spectrum was not reported. In order to confirm the structure proposed, 2D NMR experiments were performed (COSY, HSQC and $\mathrm{HMBC}$ ). According to Chatterjee et al (1965), among the aromatic protons, $\mathrm{H}-3$ is the one located at higher field in sparsiflorine. We use HSQC to locate the carbon atoms C-3, C-8, C-9 and C- 11 by the correlations with its corresponding protons. Once located C-3, the HMBC experiment allowed resolving

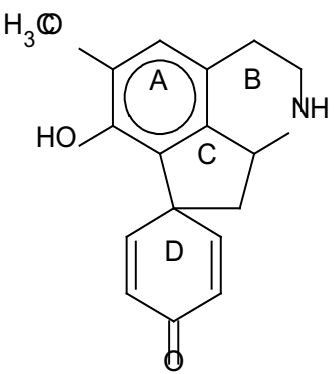

(1)

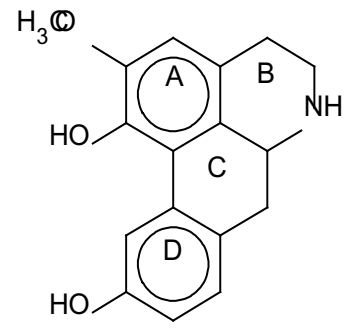

(2)
FIGURE 1. Structutes of crostsparine (1) and sparsiflorine (2) 
TABLE 2. Minimal inhibitory concentration $(\mathrm{mg} / \mathrm{mL})$ of alkaloid extract, crotsparine and sparsiflorine

\begin{tabular}{lcccccccc}
\hline Bacteria & Extract & S.D. & Crotsparine & S.D. & Sparsiflorine & S.D. & Gentamicin & S.D. \\
\hline Klebsiella pneumoniae CECT 367 & 0.625 & 0 & $>1.00$ & $\mathrm{n} / \mathrm{a}$ & 0.563 & 0,072 & 0.004 & 0.001 \\
Escherichia coli ATCC 35218 & 0.625 & 0 & $>1.00$ & $\mathrm{n} / \mathrm{a}$ & 0.813 & 0,217 & 0.008 & 0.006 \\
Pseudomonas aeruginosa CECT 108 & 0.235 & 0,906 & $>1.00$ & $\mathrm{n} / \mathrm{a}$ & 0.141 & 0,179 & 0.0005 & 0 \\
Staphylococcus aureus ATCC 25923 & 0.469 & 0,180 & $>1.00$ & $\mathrm{n} / \mathrm{a}$ & 0.875 & 0,217 & 0.002 & 0.001 \\
\hline
\end{tabular}

S.D. = standard deviation $\mathrm{n} / \mathrm{a}=$ not available

the position of the methoxy group in the A ring. $\mathrm{H}-3$ showed only three-bond correlations with carbon atoms. If the methoxy group were located at C-1, a three-bond correlation must be observed between the carbon bearing the methoxy group and $\mathrm{H}-3$. This was not the case. $\mathrm{H}-3$ showed long distance correlations with three carbons $\left(\mathrm{C}-1, \mathrm{C}-1_{\mathrm{b}}\right.$ and $\left.\mathrm{C}-4\right)$, but not with the carbon in which the methoxy group were located. Nor the other aromatic protons $(\mathrm{H}-8$, $\mathrm{H}-9$ and $\mathrm{H}-11$ ) showed three-bond correlations with the carbon bearing the methoxyl, excluding the possibility that it was located in the $\mathrm{D}$ ring. According to this, the methoxy group is located at C-2. The ${ }^{13} \mathrm{C}$ NMR data are also in agreement with that of related compounds in which the methoxy group is located at C-2 (Cassels et al., 1987). Therefore, the analysis of the data obtained showed that the isolated compound was sparsiflorine (Figure 1).

Concerning the antibacterial assay, crotsparine was revealed inactive against the tested microorganisms at the concentrations assayed, whereas the crude alkaloid extract and sparsiflorine were active, mainly against $P$. aeruginosa. The results are showed in Table 2 .

In order to establish if the differences between the MIC values obtained for the alkaloid extract and for sparsiflorine for each bacterium were statistically significant, a paired Student " $\mathrm{t}$ " test was performed. The test did not show difference between MIC values for the extract and for sparsiflorine. Evidence suggests that the activity of the extract may be due largely to the presence of sparsiflorine, although there are probably other compounds that contribute to a lesser extent.

An interesting point to consider is the fact that antibacterial activity is not found very commonly in alkaloids. Few examples are present in the literature (Karou et al., 2006; Omar et al., 2013) and this work demonstrates that it is important to look for that activity in these substances, although they are known for many years. Other issue that arises is the need to confirm the mechanism of action of this type of compounds. The finding of new mechanisms of action is a matter of extreme importance that could lead to the development of new types of antibacterial substances, considering the continuous reports of bacterial strains resistant to the drugs used clinically
(Saleem et al., 2010).

Further studies are then necessary in order to determine the effect of structure modifications on the antibacterial activity of the molecule and also, to elucidate its mechanism of action. Evaluation of other biological models is also advisable.

\section{CONCLUSIONS}

The alkaloid extract obtained from the leaves of Croton bonplandianum Baill. that grows in Paraguay contains crotsparine and sparsiflorine as its main constituents. Crotsparine does not show antibacterial activity against the bacteria assayed, whereas the alkaloid extract and sparsiflorine showed moderate activity, mainly again Pseudomonas aeruginosa. The activity of the crude alkaloid extract was not statistically different from sparsiflorine, showing that the latter could be the main bioactive molecule. Although the antibacterial activity of sparsiflorine is moderate, the structural modification of the molecule should be considerate for further studies, in order to evaluate the changes that the variations would produce in the activity of the parent compound.

\section{AKNOWLEDGMENT}

The authors wish to thanks the authorities of the Facultad de Ciencias Químicas and the Universidad Nacional de Asunción for financial support. The authors are also indebted to Professor Luciano Recalde for their assistance in collecting the specimens and Prof. Rosa Deguen of the Departamento de Botánica, Facultad de Ciencias Químicas, UNA for collecting and identifying the plant. Authors wish also to thanks Prof. Isidro G. Collado of the Departamento de Química Orgánica, Facultad de Ciencias, Universidad de Cádiz, Spain for the NMR experiments.

\section{REFERENCES}

AKENDENGUE, B. et al. Antiplasmodial activity of Uvaria klaineana. Planta Medica, v 68, n. 2, p. 167-169, 2002. BHAKUNI, D.; DHAR, M. Crotsparine, a new proaporphine alkaloid from Croton sparsiflorus Morong. Experientia, v 24, n.1, p. 10-11, 1968.

Rev. Bras. PI. Med., Campinas, v.17, n.4, supl. II, p.922-927, 2015. 
BHAKUNI, D. et al. The alkaloids of Croton sparsiflorus. Phytochemistry, v 9, p. 2573-2580, 1970.

BHAKUNI, D. et al. Biosynthesis of crotsparine, crotsparinine and sparsiflorine. Phytochemistry, v 13, p. 2767-2769, 1974.

CASSELS, B. et al. The ${ }^{13} \mathrm{C}$ NMR spectra of $1,2,10$-trioxygenated aporphines. Journal of Natural Products, v 50, n. 2, p. 297-300, 1987.

CHATTERJEE, A. et al. Structure of sparsiflorine, an alkaloid of Croton sparsiflorus Morong. Tetrahedron Letters, n. 21, p. 1539-1544, 1965.

HOSTETTMANN, K. et al. Modern screening techniques for plant extracts. Pharmaceutical Biology, v 39, s. 1, p. 18-32, 2001.

ISLAM, M. et al. In vitro evaluation of Croton bonplandianum Baill. as potential antitumor properties using Agrobacterium tumefaciens. Journal of Agricultural Technology, v 7, n. 3, p. 711-719, 2011.

JEESHNA, M. et al. Phytochemical constituents and antimicrobial studies of the exotic plant species, Croton bonplandianum Baill. Journal of Life Sciencies, v 3, n. 1, p. 23-27, 2011.

KAROU, D. et al. Antibacterial activity of alkaloids from Sida acuta. African Journal of Biotechnology, v 5, n. 2, p. 195-200, 2006.

LAHLOU, M. The success of natural products in drug discovery. Pharmacology \& Pharmacy, v 4, p. 17-31, 2013.

LEGOABE, L. Isolation and Characterisation of Antimicrobial Compounds from Antizoma angustifolia. 2004. 83p. Dissertation (Ph.D. Concentration Area in Organic Chemistry/Microbiology)

- School of Pharmacy, North-West University, South
Africa.

OMAR, $\mathrm{H}$. et al. Aporphine alkaloids from the aeaves of Phoebe grandis (Nees) Mer. (Lauraceae) and their cytotoxic and antibacterial activities. Molecules, v 18, p. 8994-9009, 2013.

PARMESHA, M. et al. Antibacterial activity of some Euphorbiaceae weeds against pathogens. The ICFAI Journal of Life Sciences, v 2, n. 2, p. 36-40, 2008.

SALEEM, M. et al. Antimicrobial natural products: an update on future antibiotic drug candidates. Natural Product Reports, v 27, n. 2, p. 238-254, 2010.

SARKER, S. et al. Microtitre plate-based antibacterial assay incorporating resazurin as an indicator of cell growth, and its application in the in vitro antibacterial screening of phytochemicals. Methods, v 42, p. 321-324, 2007.

SISODIA, S.; SIDDIQUI, M. Allelopathic effect by aqueous extracts of different parts of Croton bonplandianum Baill. on some crop and weed plants. Journal of Agricultural Extension and Rural Development, v 2, n. 1, p. 2228, 2010.

SINGH, N. et al. Evaluation of genotoxic and antimicrobial potential of Croton bonplandianum Baill. Archives of Applied Science Research, v 2, n. 2, p. 211-216, 2010.

SULEIMAN, M. et al. Detection of antimicrobial compounds by bioautography of different extracts of leaves of selected South African tree species. African Journal of Traditional, Complementary and Alternative Medicines, v 7, n. 1, p. $64-78,2010$.

UDAYA, P.N. et al. A comparative study on antibacterial activity of common weeds. International Journal of Pharma and Bio Sciences, v 2, n. 1, p. 677-683, 2011. 